\title{
A comparative study on competition laws and practices between Saudi Arabia and the United States
}

\author{
Hussain N. Agil \\ Jazan University, Saudi Arabia \\ haqil@jazanu.edu.sa
}

\begin{abstract}
:
This paper mainly compares the prevailing competition laws and practices of both the United States of America and Saudi Arabia with respect to their historical development and the legal systems of these countries. These objectives emanate from the globalization of trade and commerce, which necessitates considerable knowledge on the part of the global investors of the similarities and differences between the two countries for ease of trade. Being a comparative study, the current work adopts a comparative analysis methodology whose main objective is to evaluate the characteristics of each competition practice. Furthermore, there has been a need to reconcile the various views regarding the practices in both systems, as some deemed them similar while others advanced that they were opposites. The results of the research were quite mixed. The research established that the similarities and differences between the competition laws of both countries vary depending on each country's unique legal systems, socioeconomic practices, political organization, and legislations. Generally, some of these factors, particularly the political organization, resulted in the commercially restrictive practices culminating in price violation. A striking similarity is that both competition practices do not prohibit domination by a given business entity but instead prohibit the abuse of such dominance. Alternatively, a key difference between them is that while Saudi laws are borrowed from the Islamic Sharia laws, the American system is tailored to capitalistic principles. Notably, the Saudi laws are reflective of the much broader Islamic jurisprudence. This paper shall be essential because it deconstructs the competition practices of American Law and Islamic Jurisprudence in an easier way, hence helpful to those interested in this research area.
\end{abstract}

Keywords: Competition; Violation; Discrimination; Implementation; Anti-trust. 


\title{
دراسة مقارنة بين قوانين و ممارسات المنافسة في المملكة العربية السعودية و الولايات المتحدة الأمريكية
}

\author{
حسين عقيل \\ جامعة جازان، السعودية \\ haqil@jazanu.edu.sa
}

ملخص الاراسة

تقـارن هذه الورقـة بشـكل أساسـي قو انيـن وممارسـات المنافسـة في كل مـن الو لايـات المتحـدة الأمريكيـة

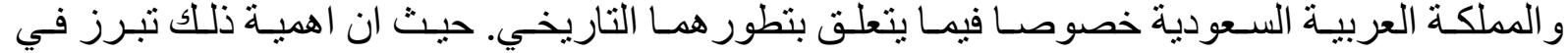

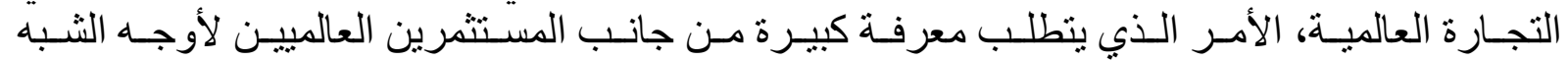

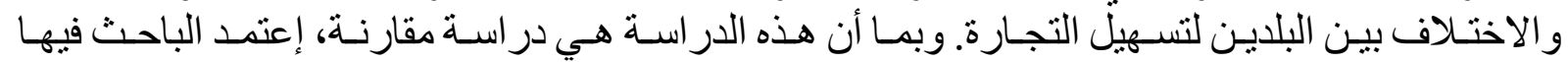

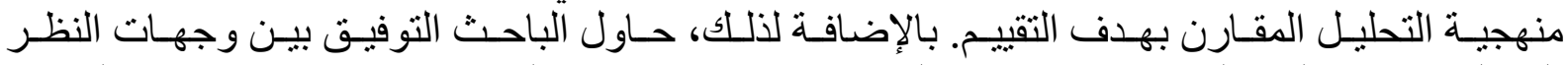

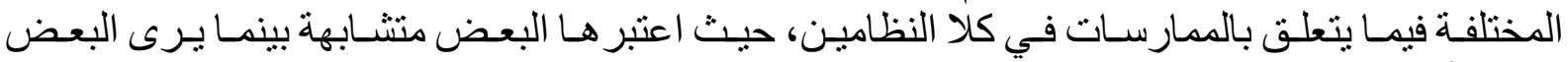
الآخر أنهـا متناقضـــــا

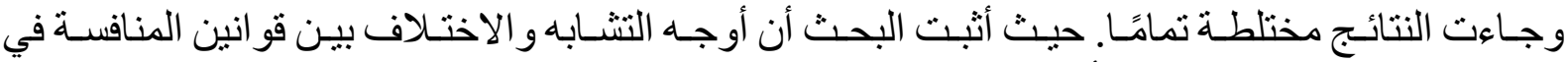

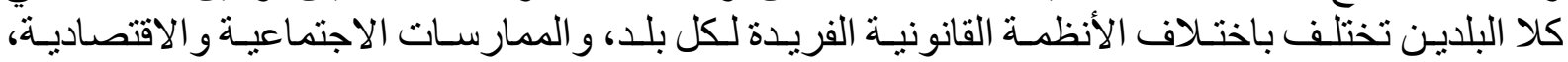

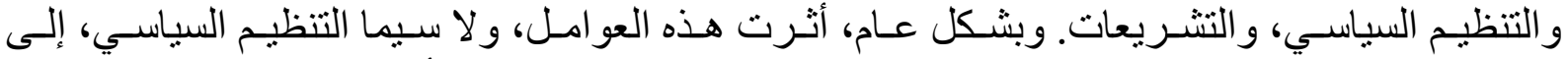

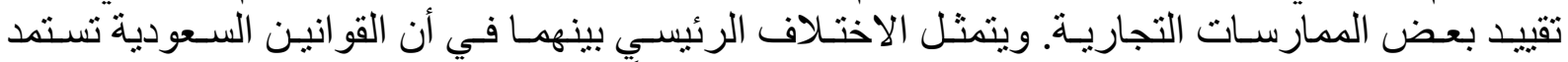

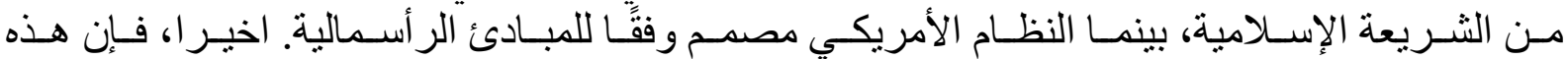

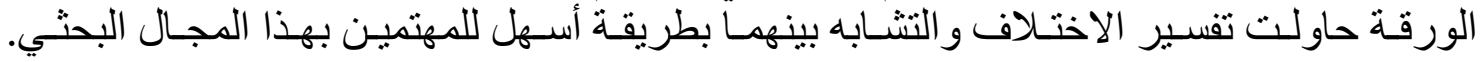
الكلمات المفتاحية: منافسة؛ انتهاك؛ تمبيز؛ تتفيذ؛ عدم ثقة. 


\section{Section One:- Research prerequisites}

\section{Introduction:}

Competition law regulations usually apply stringently on all firms with the exception of public corporations and state-owned enterprises. This is undeniably discriminatory to private firms since the former have stronger incentives, yet they are in direct competition for market share with them. Notably, the primary purpose of competition law is to protect and encourage fair competition through restrictions on economic concentration and monopolies. For instance, the competition law practices in Saudi Arabia prohibit agreements geared towards unfair competition and restrict firms' ability to acquire domination through anti-competitive practices.

This study will be divided into three Sections. The first section will discuss the prerequisites to the research such as the problem statement, aims of the study, research questions, statement of originality, scope of the study, and limitations encountered. The second section will provide a literature review on the history of Saudi Arabian and American competition laws. The third section will give an analysis and discussion of the scope of similarities and differences. Finally, the paper will summarize the results and offer recommendations.

\section{Statement of the problem:}

Competition law and practices in the US and Saudi Arabia have undeniably been affected by the conflicting sources of laws, which impacts the commercial endeavours of investors. As such, a comprehension of the underpinnings of competition laws in these countries can serve as the basis of coming up with legal frameworks that favourably advertise the countries' economical as well as political environments.

\section{Aims of the study:}

This study aims at.

1. Providing an assessment of the historical perspective of competition laws existing in both countries to assist policymaking bodies in devising best practices compatible with each country's unique requirements.

2. Providing an overview of the legal systems in both countries and evaluate their influence on the development of the respective competition laws.

3. Mapping the similarities and differences between both countryscompetition laws and culture.

4. Identifying the impact of competition laws on commercial activities and price products in each country. 


\section{Research Questions:}

The following two research questions guided the study

1. What is the historical background of competition laws in both the United States and Saudi Arabia?

2. What are the legal systems in Saudi Arabia and the United States that are concerned with competition laws?

\section{Originality Statement:}

This study builds upon existing work on competition laws in the US and Saudi Arabia,competition laws, with due care taken to recognize their authors. Despite the rich literature documenting the competition laws in Saudi Arabia and the US, most studies have taken an independent approach to discussing them exclusively. However, globalization and improved international relations prompt the comparison of integration of competition practices within and between states, which this paper addresses.

\section{Significance of Study:}

There exists a limited range of research on the implications of competition laws that transcends the boundaries of individual nations. Therefore, this study becomes important as it has the potential of ushering in a new era of research that involves conducting comparative studies among states. That being said, the study is significant because it explores the legal systems and their impacts on competition laws both in the US and Saudi Arabia. The establishment of similarities and differences can, thus, inform individual states on improvements to competition laws to positively affect commercial activities and prices of goods, and services in the US and Saudi Arabia.

\section{Scope of Study:}

The main parameter of concern for the study is competition laws between the US and Saudi Arabia. Therefore, research approaches will be applied to map the extent of differences and similarities in competition laws. Moreover, the study will succinctly address the legal systems that influence the establishment of competition laws in the US and Saudi Arabia. As such, only data relevant to the USA and Saudi Arabia will be collected for use.

\section{Methodology:}

Thus study employs a comparative analysis method which is undeniably suitable and useful. Data collected was from secondary sources such as articles and statutes.

\section{Limitations:}

There is a limited range of literature on the historical perspective as well as comparison of competition laws between Saudi Arabia and the USA. Being among the first studies of this kind, the present work has been challenged by the hardship of accessing data, which presents a potential limitation to its validity and credibility. Additionally, COVID-19 restrictions alter the normalcy of research activities such as face-to-face interviews, which had to be alternatively done via video conference in line with social distancing guidelines. 


\section{Contribution to knowledge:}

This study contributes to the existing knowledge of competition laws of independent nations by offering a comparative analysis of competition laws in the USA and Saudi Arabia, an approach rarely taken by such studies. From this analysis, relevant stakeholders can select a mix of practices that best suit to reinforce those prevailing in their countries.

\section{Section Two:- Literature Review}

\section{History of competition Laws}

\section{History of Saudi Arabia and America Competition Law:}

The competition law regime in Saudi Arabia encompasses Competition Law of 2004 adopted by Royal Decree No. M/25/04/1425H and Regulations and Competition Rules Resolution No. 126 04/09/1435H. These regulations are enforced by the Competition Council, which sets out procedural rules and guidelines for awareness and compliance. However, these rules have not remained static since their adoption in 2004.

In 2014, Saudi Arabia amended the Competition Law to mirror the developments in global economic markets. Recently, an amendment to article 12 of the competition law was introduced to enhance punishments for breaches. The article provision stipulates that "Notwithstanding any harsher punishments available, each violation is subject to a fine not exceeding $10 \%$ of its total turnover, or an equivalent of 10 million Saudi riyals. If the violation recurs, the fine will be multiplied." Such heavy punishment would undeniably discourage any business entity from engaging in anti-competition behaviour.

Regarding punishments, the violator is liable to reimburse all profits from such breach. Additionally, the Saudi legal system also includes a "name and shame" system for punishing violations. In this system, judgements are published at the expense of the violator. This shaming serves to lower the reputation and credibility of the breaching company in the public's eyes. Furthermore, the system serves to preclude the company from benefitting from certain public works tenders. All these measures serve to make breaches very expensive for the violators, and therefore they desist from them.

The United States of America was the first country to adopt a comprehensive framework of competition laws. This framework constitutes legislation like the Federal Trade Commission Act of 1914 and the Sherman Antitrust Act. The latter is highly essential as it is the fulcrum of antitrust policy mostly because it makes it illegal to restrain trade or create monopolies in the market (Facey \& Assaf, 2014). Notably, the competition laws in the USA often referred to as antitrust laws, antitrust laws in USA, are reflective of the Charter of Freedom envisioned to protect the republican values of free enterprise. 


\section{Section Three:- Analysis and discussion}

\section{Analysis and discussion:}

Anti-competitive practices and agreements in most jurisdictions are drafted to curb various practices such as price-fixing. In Saudi Arabia, Article 4 of the Competition Law prohibits agreements by firms, whether written or oral, seeking to restrict commerce and violate fair competition practices. Such agreements include alliances to dominate the free market. Apart from price-fixing, other unfair competition practices include setting cap limits on the number of goods and services to be produced, dividing markets, discriminating against clients, complicity in tenders and undervaluing products to force competitors off the market (Hamoudi \& Cammack, 2018). However, not all these practices are punishable by the Competition Council, as it has the mandate to choose not to apply the prohibitions as stipulated in Article 4 of the Competition Law. One such example is market domination

Market domination arises when a single firm generates $40 \%$ of the total sales in the market, for a continuous period of 12 months. Market domination also occurs when an entity is in a privileged position to influence the market price of goods, whether directly or indirectly. In Saudi Arabia, dominance is assessed by gauging how influential an entity is. However, caution should be taken when assessing dominance since some practices, though characteristics of dominance, do not necessarily make an entity dominant. For instance, a business may engage in price-cutting resulting a reduction of the purchase price by the consumer, yet its decision was influenced by the lowering of production costs (DeLong-Bas, 2013). When evaluated wrongly, such a business entity may suffer its decisions yet were not malicious.

The success of competition laws is mostly seen in the various legislation requirements for businesses to inform the relevant government organization when they intend to do mergers and acquisitions. In Saudi Arabia, the Competition Council enforces this requirement by assessing proposed mergers and acquisitions to determine whether the merger would grant the firm a dominant monopolistic position in the market. The Competition Council then has the discretion to approve or decline the proposed merger. As such, entities seeking to the merger must notify the Competition Council within 60 days. Notably, such mergers are also deemed complete when the council does not offer, communicate or make any objections upon the lapse of 60 days from the notification date.

As stated in the foregoing, the competition laws in Saudi Arabia do not explicitly forbid market domination. Instead, the regulations are against the abuse of such a dominating position (Daudpota, 2015). Unfortunately, dominant positions are easily abused, therefore explaining the harsh competition laws and the wary attitude the competition council adopts is needed when dealing with such mergers. Notably, Articles 4 and 6 of the Competition Law prescribe the abuse of dominant positions. It identifies such practices like price control and barriers of movement in the market as constituting a dominant position's abuse.

In case of complaints, the claimant reports to the Competition Council, who then investigates within 180 days to determine whether there is a breach, and its extent. In case of a breach, the 
defendant is notified, and a hearing is conducted within 15 days after notification. Within 10 days after the hearing is completed, the parties are informed of the council's decision. When found liable, the competition council may issue injunctions to stop the violation or issue penalties such as monetary fines not exceeding 5 million or a daily fine of not less than 1000 Saudi Riyals. Or, instead, they can issue injunctions to stop the practice. In some cases, the Competition Council may also require the liable firm to relinquish its dominant position by disposing of its assets. However, the Competition Council's decision is not final, and aggrieved parties may appeal to the Board of Grievances.

In 2019, several reforms were introduced to the Competition Law by Royal Decree No (M/75) 2019. These reforms increased the jurisdiction and scope of the competition law. For instance, a provision extended the jurisdiction of the law abroad, which means that it now applied to all firms of Saudi Arabia citizens, including those that are abroad. Additionally, the new reforms further limited the exemption of public corporations and state-owned enterprises.

Other reforms passed in the law include restrictive practices such as price recommendations, weight and quantities. For instance, article 4 sets out that the prices of commodities are set regarding the prevailing market rules, guided by the rules of free competition. The new reforms further outline all practices or contracts intended to violate the principles of fair competition. These reforms are undeniably suggestive that the Saudi Arabia government is cognizant of the emerging needs of current markets, particularly consumer protection.

When assessing violations, the Competition Council is tasked with interpreting the competition laws pertinent to the case. However, when such cases are tabled before courts, and the judges have the discretion to interpret the laws in the way they deem fit and appropriate to meet the ends of justice. Notably, the judges are not usually strictly bound by precedence, even when the facts are similar. However, the judges are obligated to apply the principles of Sharia Law from Islam, which also enforced in the businesses themselves. This is attributed to the fact that Saudi Arabia is an Islamic state, with the religion of Islam influencing the citizens' social, political and economic culture. As such, it is only fair that judges apply the principles of Islam in determining violations.

Despite this allure of uniformity and unity, requiring the application of Islam principles has brought with it a facet of problems to the judiciary. This is because the laws are vague unlike other legislation, hence leaving too much discretion vulnerable to abuse by the judges. However, the state continues to insist on its application despite the shortcomings that foreground its vitality for social cohesion.

The introduction of competition law in the United States of America was necessitated by the country's tremendous economic growth. To reflect the arising needs, the Sherman Antitrust Act of 1890 and the Clayton Act of 1914 were introduced by the federal government. Notably, the Sherman Antitrust Act mostly deals with the prohibition of agreements restraining trade as provided under Section 1 and monopolization in Section 2. On the other hand, the Clayton Act in section 7 regulates mergers and acquisitions. Regarding enforcement, courts in the US treat competition law as a form of common law in the sense that decisions and legal standards vary over time in in order to meet the ends of justice.

As noted in the foregoing, the Sherman Act of 1890 regulates the competitive market and has two main substantive sections. Section 2 makes it a felony to create a monopoly of trade or commerce and has penalties of up to $\$ 350,000$ or three years of imprisonment. Notably, the 
Sherman Act can be enforced either criminally or civilly, with the US judiciary having the biggest role in its implementation. This role is evident in United States v, Addyston Pipe \& Steel Co. 1898, which introduced the principle rule that a restraint of trade cannot be enforced unless the covenant is ancillary to the intention of the lawful contract.

In addition to the Sherman Act, other statutes that contribute to American competition law's framework include the Wilson Tariff Act of 1894, which regulates imports. In sections 73-76, the act outlines punitive sanctions for violating import laws, such as conspiring to restrain the import trade. However, such violations are reported alongside the Sherman Act, 1890, whose jurisdiction extends outside America as exemplified in Hartford Fire Insurance Co. v. California. In that case, the court held that the Sherman Act applies to foreign conduct that affects America. However, despite the Sherman Act prohibiting collusions, it still delineates corporate amalgamations, proving insufficient in dealing with anti-competitive mergers. Fortunately, the Clayton Act steps in to seal this loophole.

Undeniably, the major role of the Clayton Act 1914 is expanding the prohibitions provided by the Sherman Act. For instance, the act provides for the private enforcement of antitrust laws and the prohibition of monopolizing mergers in section 7. Notably, the Clayton Act is more elaborate on the nature of the mergers that lead to the creation of monopolies and anticompetition practices. For instance, the amendment of section 7 of the Clayton Act 1914 forbids acquisitions regardless of whether they involve stocks or assets. This amendment, therefore, closes the anti-competitive merger loophole by broadening the scope to cover both asset and stock acquisitions that achieve unlawful anti-competitive amalgamations (Kokkoris, 2007). As such, the Clayton Act is seen to supplement the Sherman Act.

In the United States, the enforcement of competition laws is entrusted to the U.S Department of Justice and the Federal Trade Commission. More often than not, these two organizations overlap in the same jurisdiction, resulting in double jeopardy. This, therefore, necessitates their cooperation in dealing with cases. Notably, FTC's jurisdiction is limited to healthcare, food, energy and internet connection services (Devlin, 2016). However, both agencies deal with arising cases differently, with the DOJ mostly relying on unlawful practices to occur before investigating and suing in the courts. On the other hand, the FTC takes a different approach.

Unlike the DOJ, investigations by the FTC are triggered by premerger notifications or congressional enquiries. Upon a belief that a violation may be committed or has already been committed, the FTC swoops in by demanding voluntary compliance through consent order with the said company. The company that gives out consent must not necessarily admit to the violation, but must stop the disputed practices or take appropriate steps to resolve the anti-competitive aspects in the merger. If the consent is not acquired, the FTC issues out an administrative complaint and seeks an injunctive in federal courts. The commission then issues a cease and desist order, before continuing to initiate formal hearing proceedings with all parties involved present, guided by the rules of natural justice (Walulik, 2019). The commission may then issue a final decision on the matter, which is appealable to the U.S Court of Appeal and the U.S Supreme Court.

The decision of the FTC may include penalties or injunctions that are confirmed by the court. Notably, when the investigations take a formal turn into courts, the FTC is mandated to cooperate with the DOJ, which has complete jurisdiction on antitrust laws (Walulik, 2019). Such cooperation may include submitting evidence to the DOJ. Additionally, state attorneys also play a part in antitrust enforcement by bringing suits on behalf of individuals (Dabbah, 2010). 
Private parties may also sue individually through civil suits to enforce antitrust laws, mostly seeking damages for violations occasioned by the breach of the Sherman and the Clayton Act.

\section{Scope of Similarities and Differences:}

Competition laws in both Saudi Arabia and the USA have a long history, yet quite explicit (Alotaibi 2019). A major similarity of both the American and Saudi Arabia competition law practices is that both systems are evaluative and reflective of the changes emerging in the economy. This is evident in the various reforms in these countries to ensure the promotion of practices that align with fair competition in business (Alese 2016; Casoria 2017). Additionally, in both countries, the relevant agencies in the countries act as watchdogs in ensuring the entities compete freely and fairly without unwarranted discrimination (Banafea and Ibnrubbian 2018; Bradford et al. 2019). Another similarity is that both countries identify similar practices that constitute both countries identify similar conducts such as price-fixing, client discrimination, manipulating prices in a way that forces competitors off the market, and dividing the market that is as constituting as anti-competitive practices (Gouda 2012; Hanafi et al. 2017; Ramady 2010). These similarities undeniably end there.

Conversely, a major difference between the two systems is that Saudi Arabia relies heavily on the principles of Sharia Law from Islam in the implementation of the competition laws, while the American system lies on precedence in common law guided by capitalist principle (DeLong-Bas 2013, Peridy and Ghoneim 2009; Memeti, 2019). This undeniably disfavors the Saudi Arabian system due to the unpredictability of decisions (Al Rajhi et al., 2012). As such, this has stunted the growth of the competition law jurisprudence in the country.

The other difference between the two systems is the difference in the enforcement of the competition laws. While America prefers the litigation process in court, Saudi Arabia savours a name and shaming system as punishment for violations (Long 2019). Apperently, these differences are mostly due to the differences in foundations of the legal systems.

\section{Conclusion:}

The preceding discussion establishes that the two countries have notable similarities in their laws, for instance, their objectives, the agencies involved, and the identification of similar anticompetitive practices. However, what mostly varies is the enforcement processes and measures, with America dealing the violations methodologically using the criminal justice system that is guided by precedence while Saudi Arabia focuses on the name and shame methods, coupled with the vague Sharia laws that enable judicial caprice. Therefore, it is no wonder that the Saudi Arabian competition law jurisprudence lags behind on maturity and development, hence warrant immediate redress.

\section{Recommendations:}

With diverse and changing markets in both Saudi Arabia and America, competition laws which have clearly been legislated differ and share commonalities in their purpose and implementation. However, there still exists major loopholes in both systems, which are undeniably detrimental. For instance, America's competition law does not effectively cover anti-competitive amalgamations due to its focus on collusions in merges only. As such, this needs proper redress to cover the gap, as seen in the attempted section 7 of the Clayton Act. Additionally, the overlap in jurisdictions among American agencies results in the derailment of justice. To avoid this overlap, the jurisdictions of both agencies should be clearly defined. 
It is recommendable that the FTC should retain complete jurisdiction regarding competition law. However, this jurisdiction should not be unchecked;therefore, it is necessary to warrant a supervisory body that the FTC should report to, such as the judiciary or Congress, to ensure the commission does not act ultra vires.

Regarding the deficiencies in Saudi Arabia, it is deemed necessary that the country should stop overreliance on the vague principles of sharia law. However, the principles may be improved by being more defined in legislation. Alternatively, the country can adopt the method of relying on precedence to enhance the decisions' predictability. 


\section{References:}

1- Almutairi, A. M. (2017). Protecting the rights of local shareholders under the Saudi rules for qualified foreign financial institutions investments in listed shares (Doctoral dissertation, Victoria University).

2- $\quad$ Al Rajhi, A., Al Salamah, A., Malik, M., \& Wilson, R. (2012). Economic Development in Saudi Arabia. Routledge.

3- Al-Abdali, O. S. (2012). Dynamics of consumer protection across Saudi Arabia. Journal for Global Business Advancement, 5(1), 40-70.

4- Alese, F. (2016). Federal antitrust and EC competition law analysis. Routledge.

5- $\quad$ Alotaibi, I. M. (2019). The role of competition law in the telecommunications sector in Saudia Arabia. (Doctoral dissertation, Brunel University London).

6- $\quad$ Alotaibi, M. (2011). Does the Saudi Competition Law Guarantee Protection to Fair Competition? A Critical Assessment. (Doctoral dissertation, University of Central Lancashire).

7- Banafea, W., \& Ibnrubbian,A. (2018). Assessment of economic diversification in Saudi Arabia through nine development plans. OPEC Energy Review, 42(1), 4254.

8- $\quad$ Bradford, A., Chilton, A., Linos, K., \& Weaver, A. (2019). The Global Dominance of European Competition Law over American Antitrust Law. Journal of Empirical Legal Studies, 16(4), 731-766.

9- Casoria, M. (2017). Competition Law in the GCC Countries: The Tale of a Blurry Enforcement. Chinese Business Review, 16(3), 141-149.

10- Clayton Act, 1914.

11- Competition law 2004 (Royal Decree No. M/25 04/05/1425H). Retrieved from https://gac.gov.sa/AdminImages/Competition_Law\%20EN\%20July2014.pdf.

12- Competition law, 2019 Competition Rules (Resolution No. 126 04/09/1435H) Retrieved from

13- https://gac.gov.sa/pdf/New_comp_law booklet 03 en.pdf.

14- Dabbah, M. M. (2010). Competition law and policy in developing countries: a critical assessment of the challenges to establishing an effective competition law regime. World Competition, 33, 457.

15- Dabbah, M. M. (2010). International and comparative competition law. Cambridge University Press. 
16- Daudpota, F. (2015). Competition law in the Kingdom of Saudi Arabia. Riyadh, KSA.

17- DeLong-Bas, N. J. (2013). Islam and Power in Saudi Arabia. In the Oxford Handbook of Islam andPolitics.

18- $\quad$ Long, D. E. (2019). The United States and Saudi Arabia: Ambivalent Allies. Routledge.

19- Devlin, A. J. (2016). Antitrust and patent law. Oxford University Press.

20- Elhauge, E., \& Geradin, D. (2011). Global competition law and economics. Bloomsbury Publishing.

21- Facey, B. A., \& Assaf, D. H. (2014). Competition and antitrust law: Canada and the United States.

22- $\quad$ Gouda, B. A. (2012). The Saudi Securities Law: Regulation of the Tadawul Stock Market, Issuers, and Securities Professionals under the Saudi Capital Market Law of 2003. Ann. Surv. Int'l \& Comp. L., 18, 115.

23- Hanafi, M., Wibisono, D., Mangkusubroto, K., Siallagan, M., \& Badriyah, M. J. K. (2017). Modelling competitive advantage of nation: a literature review. Competitiveness Review: An International Business Journal.

24- Hamoudi, H. A., \& Cammack, M. (2018). Islamic law in modern courts. Wolters Kluwer Law \& Business.

25- Alford, R. P. (1993). The extraterritorial application of antitrust laws: A postscript on hartford fire insurance Co. v. California. Va. J. Int'l L., 34, 213.

26- In Walulik, J. (2019). Harmonising regulatory and antitrust regimes for international air transport.

27- In Woude, M. H., \& In Jones, C. (2015). EU competition law handbook 2016 .

28- Jacobs, M. E. (2013). Combating anticompetitive interlocks: section 8 of the Clayton Act as a template for small and emerging economies. Fordham Int'1 LJ, 37, 643.

29- Kokkoris, I. (2007). Failing firm defence under the Clayton Act. ECLR, 28(9), 473-487.

30- Memeti, N. (2019). Evolving Dynamics in Competition Law: A GCC Perspective. Yearbook of Antitrust and Regulatory Studies (YARS), 12(19), 173-197.

31- Peridy, N., \& Ghoneim, A. (2009). Regional integration, imperfect 
competition and welfare: The experience of the greater Arab free trade area. Economies Appliqué, 62(4), 131.

32- Ramady, M. A. (2010). Saudi Arabia and the WTO. In The Saudi Arabian Economy (pp. 289-320). Springer, Boston, MA.

33- Sherman Act, 1890 Statutes

34- Slay, B. (Ed.). (2019). De-monopolization and competition policy in postcommunist economies. Routledge.

35- Country, E. (1898). Mimeo, April 2006. United States v. Addyston Pipe \& Steel Co, 85, 570-1.

36- Taussig, F. W. (1894). The Tariff Act of 1894. Political Science Quarterly, 9(4),585-609. 
